АКАДЕМИЯ НАУК РЕСПУБЛИКИ ТАТАРСТАН

МАРИЙСКИЙ ГОСУДАРСТВЕННЫЙ УНИВЕРСИТЕТ

\title{
ПОВОЛЖСКАЯ АРХЕОЛОГИЯ
}

№ 1 (19)

2017 


\section{Главный редактор}

член-корреспондент АН РТ, доктор исторических наук А.Г. Ситдиков

\section{Заместители главного редактора:}

член-корреспондент АН РТ, доктор исторических наук Ф.Ш. Хузин

доктор исторических наук Ю.А. Зеленеев

Ответственный секретарь- кандидат ветеринарных наук Г.Ш. Асылгараева

\section{Редакционный совет:}

Р.С. Хакимов- вице-президент АН РТ (Казань, Россия) (председатель)

Х.А. Амирханов- член-корреспондент РАН, доктор исторических наук, профессор (Махачкала, Россия)

И. Бальдауф- доктор наук, профессор (Берлин, Германия)

С.Г. Бочаров- кандидат исторических наук (Симферополь, Россия)

П. Георгиев- доктор наук, доцент (Шумен, Болгария)

Е.П. Казаков- доктор исторических наук (Казань, Россия)

Н.Н. Крадин- член-корреспондент РАН, доктор исторических наук, профессор (Владивосток, Россия)

А. Тюрк- $\mathrm{PhD}$ (Будапешт, Венгрия)

И. Фодор- доктор исторических наук, профессор (Будапешт, Венгрия)

В.Л. Янин- академик РАН, доктор исторических наук профессор (Москва, Россия)

\section{Редакционная коллегия:}

А.А. Выборнов - доктор исторических наук, профессор (Самара, Россия)

М.Ш. Галимова - кандидат исторических наук (Казань, Россия)

Р.Д. Голдина - доктор исторических наук, профессор (Ижевск, Россия)

И.Л. Измайлов - доктор исторических наук (Казань, Россия)

С.В. Кузьминых - кандидат исторических наук (Москва, Россия)

А.Е. Леонтьев - доктор исторических наук (Москва, Россия)

Т.Б. Никитина - доктор исторических наук (Йошкар-Ола, Россия)

Ответственный за выпуск:

Б.Л. Хамидуллин - кандидат исторических наук (Казань, Россия)

Адрес редакции:

420012 г. Казань, ул. Бутлерова, 30

Телефон: (843) 236-55-42

E-mail: arch.pov@mail.ru

http://archaeologie.pro

Индекс 31965, каталог «ПОЧТА РОССИИ»

Выходит 4 раза в год

(C) Академия наук Республики Татарстан, 2017

(C) ФГБОУ ВО «Марийский государственный университет», 2017

(C) Журнал «Поволжская археология», 2017 


\title{
Editor-in-Chief:
}

Corresponding Member of the Tatarstan Academy of Sciences, Doctor of Historical Sciences A. G. Sitdikov

\section{Deputy Chief Editors:}

Corresponding Member of the Tatarstan Academy of Sciences, Doctor of Historical Sciences F. Sh. Khuzin Doctor of Historical Sciences Yu.A. Zeleneev

Executive Secretary - Candidate of Veterinary Sciences G. Sh. Asylgaraeva

\section{Executive Editors:}

R.S. Khakimov - Vice-Chairman of the Tatarstan Academy of Sciences (Institute of History named after Shigabuddin Mardzhani, Tatarstan Academy of Sciences, Kazan, Russian Federation) (chairman)

Kh.A. Amirkhanov - Doctor of Historical Sciences, Professor, Corresponding Member of the Russian Academy of Sciences (Dagestan Regional Center of the Russian Academy of Sciences, Makhachkala, Russian Federation)

I. Baldauf - Doctor Habilitat, Professor (Humboldt-Universität zu Berlin, Berlin, Germany)

S. G. Bocharov- Candidate of Historical Sciences (Institute of Archaeology of Crimea of Russian Academy of Sciences. Simferopol, Russian Federation)

P. Georgiev - Doctor of Historical Sciences (National Archeological Institute with Museum, Bulgarian Academy of Sciences, Shumen Branch, Shumen, Bulgaria)

E.P. Kazakov - Doctor of Historical Sciences (Institute of Archaeology named after A. Kh. Khalikov, Kazan, Russian Federation)

N. N. Kradin - Doctor of Historical Sciences, Corresponding Member of the Russian Academy of Sciences (Institute of History, Archaeology and Ethnology, Far East Branch of the Russian Academy of Sciences, Vladivostok, Russian Federation)

A. Türk - PhD (Institute of History, Research Centre for the Humanities, Hungarian Academy of Sciences, Budapest, Hungary)

I. Fodor - Doctor of Historical Sciences, Professor (Hungarian National Museum, Budapest, Hungary) V.L. Yanin - Doctor of Historical Sciences, Professor (Academician of the Russian Academy of Sciences (Moscow, Russian Federation)

\section{Editorial Board:}

A.A. Vybornov - Doctor of Historical Sciences, Professor (Samara State Academy of Social Sciences and Humanities, Samara, Russian Federation)

M. Sh. Galimova - Candidate of Historical Sciences (Institute of Archaeology named after A. Kh. Khalikov, Kazan, Russian Federation)

R.D. Goldina - Doctor of Historical Sciences, Professor (Udmurt State University, Izhevsk, Russian Federation)

I. L. Izmaylov - Doctor of Historical Sciences (Institute of Archaeology named after A. Kh. Khalikov, Kazan, Russian Federation)

S.V. Kuzminykh - Candidate of Historical Sciences (Institute of Archaeology of the Russian Academy of Sciences, Moscow, Russian Federation)

A. E. Leont'ev - Doctor of Historical Sciences (Institute of Archaeology of the Russian Academy of Sciences, Moscow, Russian Federation)

T. B. Nikitina - Doctor of Historical Sciences (Mari Research Institute of Language, Literature and History named after V.M. Vasilyev, Yoshkar-Ola, Russian Federation)

Responsible for Issue- Candidate of Historical Sciences B. L. Khamidullin

\section{Editorial Office Address:}

Butlerov St., 30, Kazan, 420012, Republic of Tatarstan, Russian Federation

\author{
Telephone: (843) 236-55-42 \\ E-mail: arch.pov@mail.ru \\ http://archaeologie.pro
}

(C) Tatarstan Academy of Sciences (TAS), 2017

(C) Mari State University, 2017

(C) "Povolzhskaya Arkheologiya" Journal, 2017 


\section{СОДЕРЖАНИЕ}

\section{Исследования и публикации}

Никитин В.В. (Йошкар-Ола, Россия).

На стыке двух тысячелетий (Марийской археологической

экспедиции 60 лет).

Житенев В.С. (Москва, Россия).

Новое свидетельство использования серпентинитового сырья

в Каповой пещере (Южный Урал).

Bugrov D.G., Galimova M.Sh. (Kazan, Russian Federation).

Antler Sleeves from the Neolithic Lake-Dwelling Sites

of Switzerland (the "Swiss Collection" of the National Museum

of Tatarstan Republic, Kazan)

Выборнов А.А. (Самара, Россия).

Спорные вопросы изучения раннего неолита Марийского Поволжья .........38

Чижевский А.А., Шипилов А.В. (Казань, Россия),

Капленко Н.М. (Н.Челны, Россия).

Итоги исследования Каентубинской Островной стоянки в 2004 году

Королев А.И., Шалапинин А.А. (Самара, Россия).

Поселение Лебяжинка VI - памятник эпохи энеолита

в лесостепном Поволжье.

Патрушев В.С. (Казань, Россия).

«Текстильная» керамика Марийского Поволжья

(по материалам раскопок поселений эпохи бронзы)

Савельев Н.С. (Уфа, Россия).

О южной границе лесных и лесостепных культур

на Урале в I тысячелетии до н.э.

Иванов В.А. (Уфа, Россия).

Памятники эпохи раннего железного века - средневековья Южного

Предуралья: источниковедческий контекст (лес и лесостепь)

Лукпанова Я.А. (Уральск, Казахстан).

Реконструкция женского костюма из элитного погребения Таксай-1:

взгляд археолога

Алтынбеков К., Досаева Д.К. (Астана, Казахстан).

Опыт реконструкции «археологического» костюма.

Голдина Р.Д., Берни В.А. (Ижевск, Россия).

Хронология мужских погребений III-V вв.

Тарасовского могильника. Часть II

Вихляев В.И. (Саранск, Россия).

Могильники мордвы III-V вв. и проблема единства древней культуры ...205 
Красноперов А.А., Черных Е.М. (Ижевск, Россия).

Женский головной убор из Дубровского могильника IV-V вв. н. э.

Голдина E.B., Черных Е.M. (Ижевск, Россия).

Бусы Дубровского могильника IV-V вв. в Среднем Прикамье:

классификация и использование

Останина Т.И. (Ижевск, Россия).

Наборные пояса из Кузебаевского клада VII века

Никитина Т.Б. (Йошкар-Ола, Россия).

Работы Марийской археологической экспедиции по изучению

средневековых древностей Поветлужья ....

Белавин А.М., Крыласова Н.Б. (Пермь, Россия).

Древнерусские материалы в Пермском Предуралье X-XI вв.

Акилбаев А.В. (Йошкар-Ола, Россия).

Смена инвентаря в погребениях середины XI-XIII веков

могильников Нижнего Поветлужья

Михеев А.В. (Йошкар-Ола, Россия).

К методике определения границ территории объектов

археологического наследия (на опыте работы МарАЭ).....

Кузьминых С.В. (Москва, Россия),

Марийская археологическая экспедиция: люди и судьбы

\section{Критика и библиография}

Ставицкий В.В. (Пенза, Россия).

Рецензия на монографию: Мордовские племена накануне великого переселения народов (Усть-Узинский могильник III-IV Вв.): монография / В.В. Гришаков, С.Д. Давыдов, О.В. Седышев, А.Н. Сомкина; Мордов.гос. пед. ин-т. . Саранск, 2016. 195 с.

\section{Хроника}

Чижевский А.А. (Казань, Россия), Кузьминых С.В. (Москва, Россия).

Научная конференция «Ананьинский мир:

культурное пространство, связи, традиции и новации».

Никитина Т.Б., Никитин В.В. (Йошкар-Ола, Россия).

О работе межрегиональной научной конференции «Проблемы сохранения и популяризации археологического наследия»

Список сокращений .360

Правила для авторов .363 


\section{CONTENTS}

\section{Researches and Publications}

Nikitin V.V. (Yoshkar-Ola, Russian Federation).

On the Turn of Two Millennia

(60 Years of the Mari Archaeological Expedition).

Zhitenev V.S. (Moscow, Russian Federation).

New Evidence of Serpentinite Raw Material Exploitation

in the Kapova Cave (The Southern Urals)

Bugrov D.G., Galimova M.Sh. (Kazan, Russian Federation).

Antler Sleeves from the Neolithic Lake-Dwelling Sites

of Switzerland (the "Swiss Collection" of the National Museum

of Tatarstan Republic, Kazan).

Vybornov A.A. (Samara, Russian Federation).

Controversial Questions of the Early Neolithic Studies

in the Mari Volga Region.

Chizhevsky A.A., Shipilov A.V. (Kazan, Russian Federation),

Kaplenko N.M. (N. Chelny, Russian Federation).

Study Results on Kaen-Tube Island Site in 2004

Korolyov A.I., Shalapinin A.A. (Samara, Russian Federation).

Lebyazhinka VI Settlement: Eneolithic Site in the Forest-Steppe Volga Region ....71

Patrushev V.S. (Kazan, Russian Federation).

"Textile" Ceramics of Mari Volga (by the Materials of Excavations

on the Bronze Age Settlements)

Savelev N.S. (Ufa, Russian Federation).

On the Southern Border of the Forest and Forest-Steppe Cultures

in the Urals in the $\mathrm{I}^{\text {st }}$ Millennium BC

Ivanov V.A. (Ufa, Russian Federation).

Early Iron Age and Medieval Sites in the Southern Ural Region:

Context of Sources (Forest and Forest-Steppe).....

Lukpanova Ya.A. (Ural'sk, Kazakhstan).

Reconstruction of Female Costume From the Elite Burial Ground

Taksay-I: a View of the Archaeologist

Altynbekov K., Dosayeva D. (Astana, Kazakhstan).

Experience of a Reconstruction of "Archaeological" Costume.

Goldina R.D., Bernts V.A. (Izhevsk, Russian Federation).

Chronology of $3^{\text {rd }}-5^{\text {th }}$ Centuries Male Graves

from the Tarasovo Burial Ground.

Vikhljaev V.I. (Saransk, Russian Federation).

Mordovian Cemeteries of $3^{\text {rd }}-5^{\text {th }}$ Centuries and the Unity

of Their Early Culture. 
Krasnopeorov A.A., Chernykh E.M. (Izhevsk, Russian Federation).

Female Headdress from Dubrovskiy Burial Ground of $4^{\text {th }}-5^{\text {th }}$ Centuries

Goldina E.V., Chernykh E.M. (Izhevsk, Russian Federation).

Beads of the Dubrovskiy Burial Ground $\left(4^{\text {th }}-5^{\text {th }}\right.$ Centuries A.D.)

in the Middle Kama Region: Classification and Use.

Ostanina T.I. (Izhevsk, Russian Federation).

The Seventh Century Composite Belts from Kuzebaevo Hoard

Nikitina T.B. (Yoshkar-Ola, Russian Federation).

Progress of Mari Archaeological Expedition in Study

of Medieval Antiquities of Vetluga Region

Belavin A.M., Krylasova N.B. (Perm, Russian Federation).

Ancient Russian Materials in the Perm Cis-Urals

During the $10^{\text {th }}-11^{\text {th }}$ Centuries

Akilbaev A.V. (Yoshkar-Ola, Russian Federation).

Change of Grave Goods in the Middle $11^{\text {th }}-13^{\text {th }}$ Centuries

in the Burial Grounds in the Lower Vetluga Area

Mikheev A.V. (Yoshkar-Ola, Russian Federation).

Delineating Sites of Archaeological Heritage: Methodology Based

on Endeavours of the Mari Archaeological Expedition

Kuzminykh S.V. (Moscow, Russian Federation).

Mari Archaeological Expedition: People and Destinies

\section{Critics and Bibliography}

Stavitsky V.V. (Penza, Russian Federation).

Review of the Monograph: Mordvinia's Tribes on the Eve of the Great

Migration (Ust-Uzinsky Burial $3^{\text {rd }}-4^{\text {th }}$ Cent.): Monograph / V.V. Grishakov,

S.D. Davidov, O.V. Syedyshev, A.N. Somkina. Saransk, 2016. 195 P.

\section{Chronicle}

Chizhevsky A.A. (Kazan, Russian Federation),

Kuzminykh S.V. (Moscow, Russian Federation).

Scientific Conference 'Ananyino World: Cultural Space, Connections,

Traditions and Innovations'

Nikitina T.B., Nikitin V.V. (Yoshkar-Ola, Russian Federation).

On Proceedings of the Inter-Regional Scientific Conference

on Conservation and Popularization of Archaeological Heritage

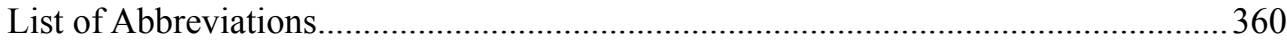

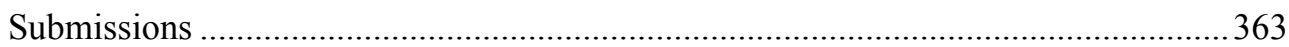




\title{
К МЕТОДИКЕ ОПРЕДЕЛЕНИЯ ГРАНИЦ ТЕРРИТОРИИ ОБЬЕКТОВ АРХЕОЛОГИЧЕСКОГО НАСЛЕДИЯ (НА ОПЫТЕ РАБОТЫ МАРАЭ)
}

\author{
(C) 2017 г. А.В. Михеев
}

В статье проанализирован опыт работы Марийской археологической экспедиции с 2011 по 2016 годы по определению границ объектов культурного (археологического) наследия на основе методики, рекомендованной Министерством культуры Российской Федерации. В процессе практической работы были выработаны рекомендации по совершенствованию отдельных положений методики применительно к различным типам памятников на территории Марий Эл. Автором внесены предложения по корректировке соответствия методических положений по определению границ с нормативными инструкциями Института археологии РАН при проведении полевых работ и существующим законодательством по охране культурного наследия.

Ключевые слова: археология, Волго-Камский регион, Республика Марий Эл, Марийская археологическая экспедиция, памятник археологии, границы объекта археологии, культурное наследие, методика.

Работы по определению границ территории объектов культурного (археологического) наследия МарАЭ ведутся с 2011 года, когда стал вопрос о количестве памятников в зоне влияния Чебоксарской ГЭС, степени их разрушения и территории, ими занимаемой. Площадь определялась по распространению культурного слоя и подъемного материала, визуально фиксируемым объектам, отчасти по топографическим особенностям местности. В течение полевого сезона на предмет определения границ было обследовано более 80 объектов археологии (Михеев, 2011; Ефремова, 2012). Основную массу составляли поселенческие памятники, которые имели внешние признаки в виде западин от древних жилищ. Можно говорить о том, что при исследованиях в зоне затопления Чебоксарского водохранилища, проводимых МарНИИЯЛИ совместно с ИА РАН, практически проверялись те положения, которые в настоящее время рекомендованы Министерством культуры РФ. В первую очередь, имеется в виду «Письмо Минкультуры РФ от 27.01.2012 № 12-01-39/05-АБ «О Методике определения границы территории объекта археологического наследия». В период с 2012 по 2016 год работы по определению границ объектов археологии были уже не такими масштабными (Акилбаев, 2012; Ефремова, 2012; Михеев, 2014, 2015). По сути, методом проб и ошибок велась работа по уточнению положений «Методики...» применительно к различным типам памятников на территории Марий Эл. Результаты проведенных исследований стали предметом рассмотрения в данной статье.

Основной целью рассматриваемого вида работ «Методикой...» признаются картографическая привязка и определение координат (в системе WGS-84 или MCK) границ объекта археологического наследия. Опыт по- 
казывает, что системы WGS и МСК значительно отличаются друг от друга в плане погрешности: в первом случае она исчисляется метрами, во втором сантиметрами. Поэтому весь комплекс работ лучше сразу выполнять в местной системе координат, что значительно упрощает законодательное закрепление объекта археологии в реестре.

Определение границ памятников археологии - действительно интересная и очень нужная работа, которая требует не только знаний специфики объекта исследования и опыта полевой работы, но и знания современного законодательства. Глазомерные планы, как показывает практика, не соответствуют реальным границам памятников. Конечно, методика таких работ пока отрабатывается и уточняется, но основная практическая значимость заключается в обеспечении юридической защищенности памятника путем включения сведений о границах территорий объектов культурного наследия (ОКН) в государственный кадастр недвижимости. Важным моментом проведения таких работ является и осуществление мониторинга состояния памятников археологии. Как следствие в ходе исследований не только уточняются и корректируются границы, но часто могут поменяться культурная принадлежность памятника и соответственно датировка.

Согласно пункту 3.2. «Методики...» определение границ выявленного объекта археологического наследия осуществляется на основании анализа нескольких составляющих, касающихся территории, местоположения, характеристики сооружений, места сбора и расположения находок, участков фиксации культурного слоя; ландшафтно-топографической и антропогенной ситуации, архивной и музейной информации. Относительно непосредственно археологических работ, связанных с определением границ объектов археологического наследия (ОАН), предполагается три этапа: изучение архивных источников (кем и когда открыт, место расположения, датировка, культурная принадлежность); полевые (натурные) исследования (закладка шурфов, уточнение привязок и топоплана, датировки, культурной принадлежности, определение границ распространения культурного слоя); написание отчета. Разберем по порядку.

Наиболее легкий путь в работе с архивами, в частности при составлении исторической справки, может ограничиваться выписками из опубликованных источников: «Атлас» или «Карта» археологических памятников. В действительности в них содержатся краткие сведения, но нет, пожалуй, основного - графического материала, в котором даются топоплан, места шурфовки и/или сбора подъемного материала. Отсутствие первоисточника (полевых зарисовок, отчета) порождает целую череду неточностей и часто грубых ошибок. Учитывая, что большая часть памятников археологии не обследовалась в течение последних 20-40 лет, в настоящее время наиболее проблемным является обнаружение ранее открытых памятников археологии. Иногда ситуация меняется кардинально: изменение русла реки, пересыхание водоема, лесоустроительные работы (вырубка или посадка деревьев), активное хозяйственное освоение территории и т.П. Они усугубляются и отсутствием у наших предшественников инстру- 
ментальной топосъемки, привязок по GPS-навигатору и других технических новшеств современности. В результате появляются вопросы типа: «А тот ли это памятник?».

Если современному исследователю повезло и объект соответствует заявленному местоположению и названию, то проблем в составлении нового топоплана и привязок к ближайшему населенному пункту не возникает. Далее все зависит от постановочных шурфов, количество которых и местоположение определяется исходя из специфики и типа конкретного памятника. При этом принципиальных отличий в определении границ распространения культурного слоя нет. Иными словами, если в шурфе/ шурфах зафиксирован культурный слой, то на прилегающей территории необходимо забить шурф/шурфы, свидетельствующие об отсутствии культурного слоя, и наоборот.

Непосредственно при проведении полевых исследований было выявлено своеобразие археологических работ по определению границ и их коренное отличие от того, что понимается под «археологической разведкой». Во-первых, классическая разведка предполагает фиксацию новых (выявленных) памятников археологии с определением их культурной принадлежности, датировки и границ. Во-вторых, мониторинг известных объектов археологии на предмет их современного состояния. Ни первое, ни второе не предполагают закладку большого количества постановочных шурфов. Границы определяются по геоморфологии (дюна, мыс и т.п.), визуально заметным признакам (жилищная западина, курганная насыпь, вал, ров городища и т.п.) и/или рас- пространению подъемного материала. Получаем в итоге, что при прохождении какого-либо конкретного выбранного разведочного маршрута границы выявленных объектов археологии определяются приблизительно. На практике, в 90\% случаях, реальные границы существенно отличаются. Исключение составляют археологические исследования в пределах территорий выделяемых под хозяйственное освоение, где точное определение границ выявленного объекта - важнейшая составляющая, которая требует наличия у исследователя достаточных знаний и опыта полевой работы.

Важно понимать, что у каждого объекта археологии существует своя специфика в определении границ. Рассмотрим наиболее распространенные на территории Марий Эл типы археологических памятников и их особенности.

На поселениях эпох камня и бронзы в подавляющем большинстве случаев жилищные западины визуально фиксируются на современной дневной поверхности. Что нужно знать при определении их границ? Во-первых, за пределами видимых границ впадин культурный слой, а тем более находки, как правило, отсутствуют. Во-вторых, в составе поселения могут быть как визуально фиксируемые впадины, так и невыраженные, что вполне объяснимо для песчаного грунта. Кроме того, впадины могут быть засыпаны в результате антропогенного влияния. В этом случае необходимы полевые чертежи предшественников, которые вкупе с постановочными шурфами помогают определить в современном рельефе изначально зафиксированные котлованы от древних жилищ (рис. 1). В-третьих, следует учиты- 

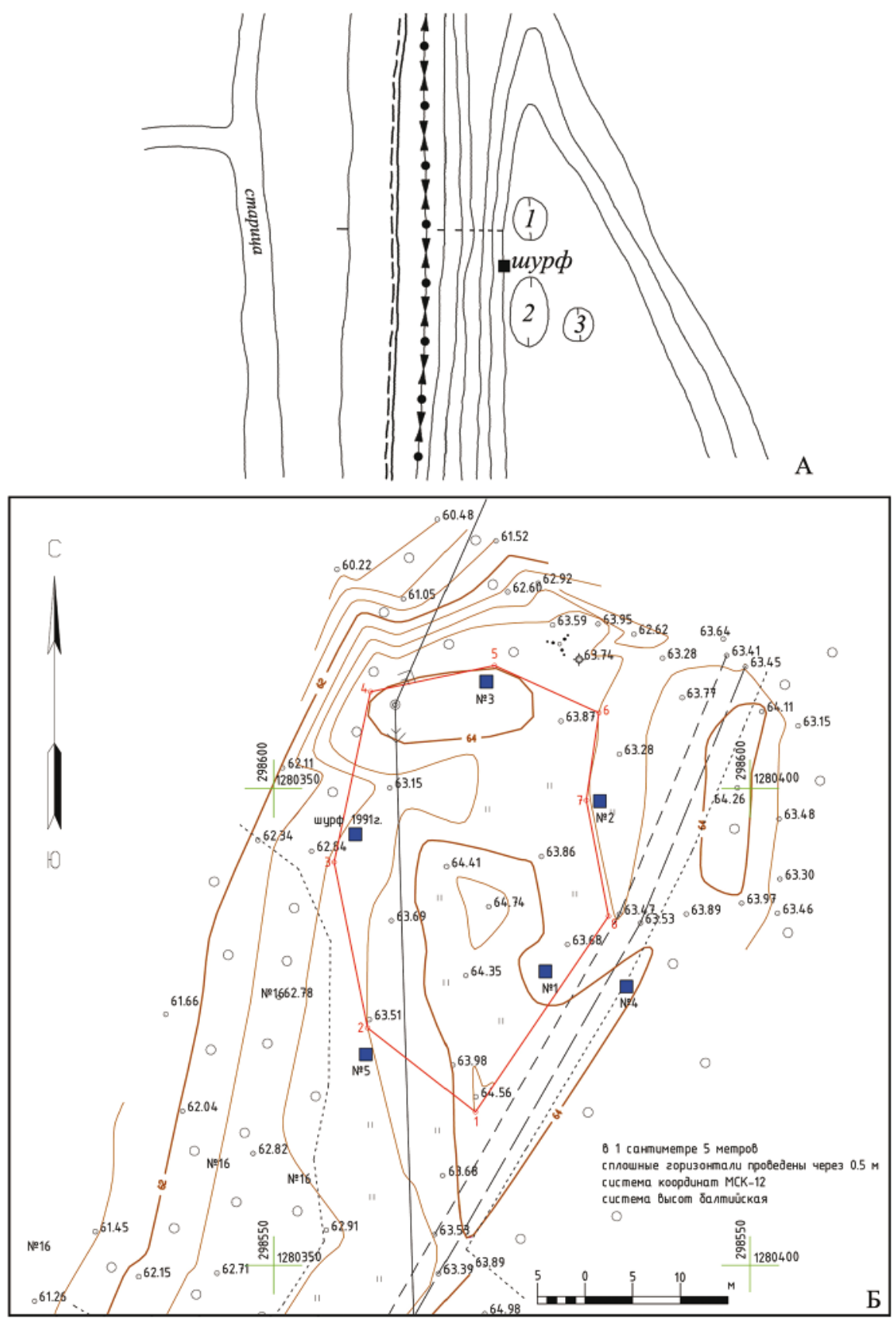

Рис. 1. Красный Яр, стоянка II. Топографический план. А - 1991 г. (по В.В. Никитину), Б - 2014 г.

Fig. 1. Krasnyi Yar, site II. Topographic plan. A - 1991 (after В.В. Никитин), Б - 2014. 
вать расположение источника воды. Как правило, границы очерчиваются по распространению культурного слоя на склоне верхней части дюны (возвышенности, мыса и т.д.) или по краю террасы. При этом выходы от поселения/жилища к воде не учитываются. Постановочным шурфом такой объект (тропа) выявить очень сложно или практически не реально. Кроме того, визуально фиксируемые впадины не отражают реального размера древней постройки (рис. 2). Это дает возможность воспользоваться пунктом 7.6.3. «Методики...»: «В случае если культурный слой, археологический объект, археологический материал (находки и предметы), связанные с каким-либо этапом функционирования объекта археологического наследия, расположен за пределами границ, определяемых по подошве естественного возвышения, но не более чем на расстоянии 25 м от нее, необходимо определить территорию распространения слоя (объектов, материала) для включения ее в границы территории объекта археологического наследия». Соответственно остается констатировать, что границы распространения культурного слоя и объектов не совпадают с общими границами памятника археологии. И постановка шурфов должна производиться так, чтобы были подтверждены реальные границы распространения культурного слоя, то есть шурф с культурным слоем должен подтверждаться шурфом без признаков культурного слоя. Например, в 2013 году разведочным отрядом МарАЭ определялись границы объекта археологического наследия «Шалангуш, поселение 8» (рис. 3). Была произведена шурфовка по периметру визуально фиксируе- мых жилищных впадин. Все шурфы подтверждают наличие культурного слоя поселения, граница была проведена по внешней стороне шурфов максимум в 5 метрах. При работах 2015 года, проводившихся в связи с выделением территории под зону хозяйственного освоения, произведена дополнительная шурфовка, в результате которой площадь памятника по распространению культурного слоя увеличилась более чем на 200 кв. м.

Опыт показывает, что для определения границ поселений достаточно забить шурфы по периметру впадин визуально фиксируемых на момент обследования и отмеченных на топографических планах предшественниками. Для определения характера культурного слоя (культурной принадлежности и датировки), особенно если памятник является выявленным объектом и шурфовки на нем ранее не производились, необходимы шурфы в межжилищном пространстве. В какой-то степени это позволяет выяснить и характер самих впадин: искусственные сооружения или естественные формы рельефа. Идеальным является закладка постановочного шурфа во впадине, но это запрещено методикой полевых исследований.

Поселения/селища открытого типа эпох раннего железного века (РЖВ) и средневековья в большинстве случаев не имеют визуальных признаков. Топографическая граница также часто не выражена, особенно если памятник расположен на дюне в пойме, то есть, по сути, имеется одна топографическая особенность: край террасы/дюны. Пункт 7.2. «Методики...» гласит: «Граница территории объекта археологического наследия определяется на местности по резуль- 

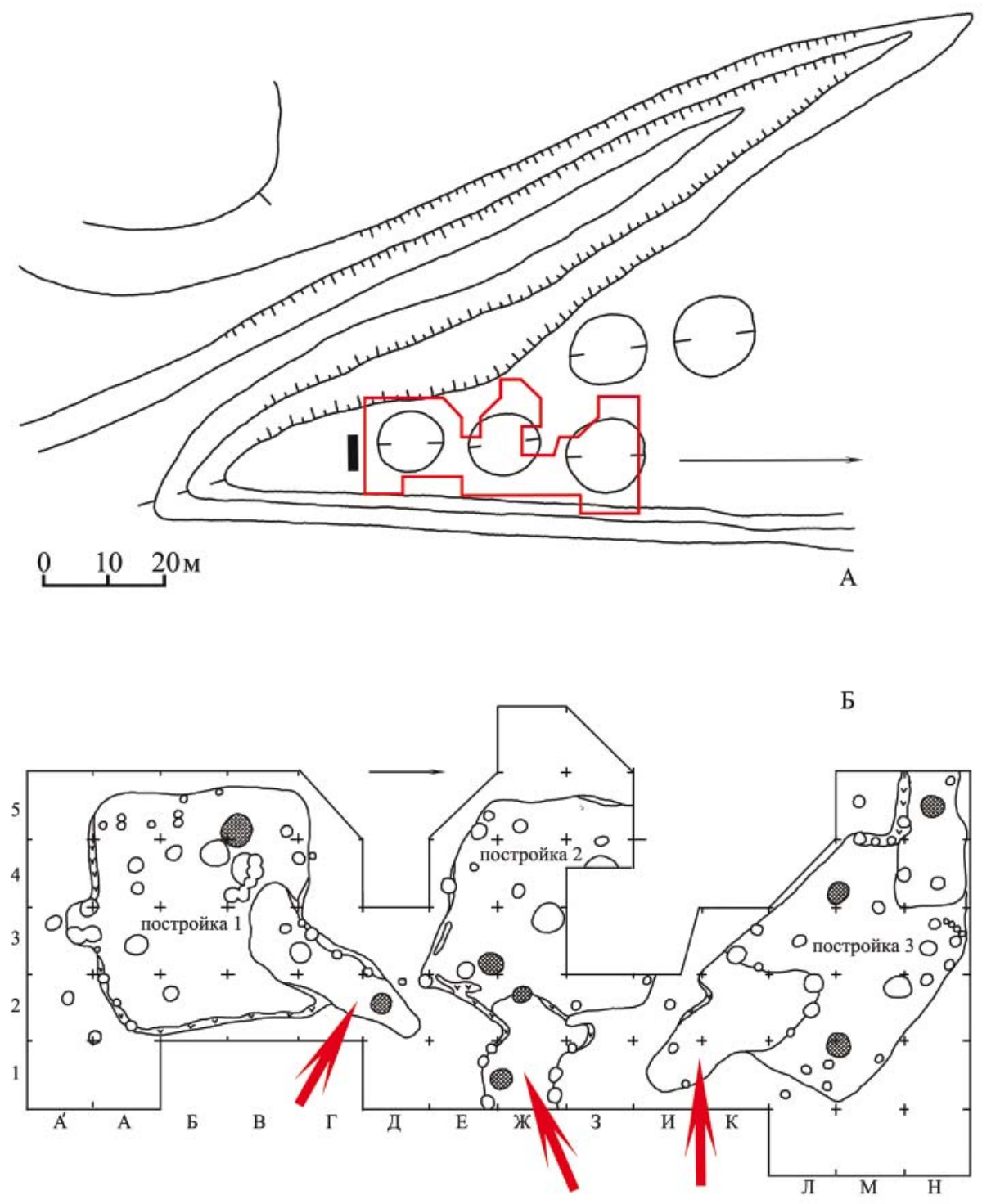

Рис. 2. Кокшамарское II поселение (по В.В. Никитину, Б.С. Соловьеву, 2002, Табл. 26, 1). А - топографический план, Б - план раскопа.

Fig. 2. Kokshamary II settlement (after В.В. Никитин, Б.С. Соловьев, 2002, Табл. 26, 1). A - topographic plan, Б - dig plan. 


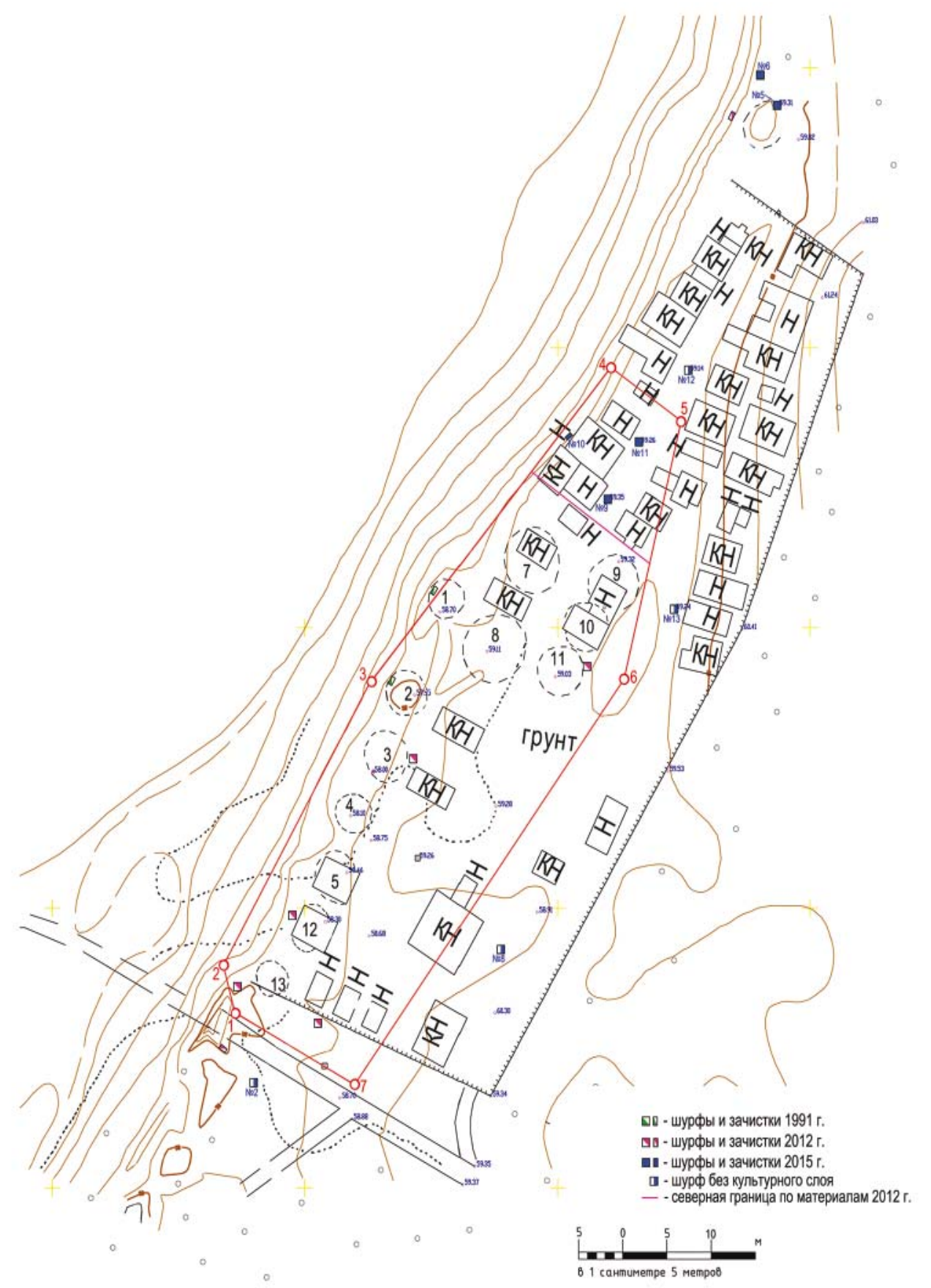

Рис. 3. Шелангушское VIII поселение. Топографический план.

Fig. 3. Shelangush VIII settlement. Topographic plan. 
татам проведенных археологических (естественнонаучных) исследований, особенностям элементов рельефа (подошва террасы или гривы, лог, овраг, ложбина и т.д.), границам растительных зон или условно, на расстоянии не менее 25 м от крайних визуально определимых археологических сооружений, обнажений культурного слоя, мест скоплений археологических предметов». Таким образом, в случае выделения земель под хозяйственное освоение, исследованиям будет подвержена вся площадь, очерченная и утвержденная в кадастре согласно установленным границам.

Однако фиксация границ таких объектов по распространению подъемного материала - самый простой выход, но и менее всего отражающий реальную площадь, занимаемую памятником. Поясню. Если территория распахивалась на протяжении последних ста лет, то при залегании культурного слоя на глубине менее 40 см площадь распространения находок могла увеличиться в несколько раз, а не на 25 м от границ культурного слоя. Конечно, объектом охраны является не только культурный слой памятника как таковой, но и артефакты, связанные с периодом существованием объекта археологии. Вероятно, имеет смысл определять и отделять границы распространения культурного слоя и границы распространения находок из этого слоя с тем, чтобы изначально обозначить различные виды археологических работ: археологические раскопки и археологические наблюдения соответственно в случае попадания территории в зону хозяйственного освоения.

Есть определенные наработки и в определении границ укрепленных по- селений - городищ. В идеальном варианте распространение культурного слоя ограничивается валом, рвом и склонами мыса, как, например, на городищах у с. Пайгусово или д. Красная Горка (рис. 4). С учетом оползания склонов граница определяется по подошве террасы и включает в себя все выступы и площадки террасы, то есть, поскольку имеются четкие топографические границы - склоны террасы и вал/ров, - необходимости шурфовки нет. Однако имеются обстоятельства, которые нельзя обойти. Практика показывает, что большинство площадок «жилой зоны» городищ являются многослойными. При этом более раннее поселение может являться поселением открытого типа, и его культурный слой распространяется за пределы визуально фиксируемых оборонительных сооружений (вал, ров). В качестве примера можно привести Ардинское городище, где оборонительные сооружения построены во второй половине I тыс. н.э., а культурный слой ананьинской эпохи со стороны напольной площадки распространяется более чем на 30 м (рис. 5). При этом слой РЖВ является неотъемлемой частью культурных напластований городища, и границы памятника в данном случае будут включать не только ограниченную валом и рвом территорию, но и всю территорию со слоем ананьинской эпохи. В данном случае получается, что городище является одним из элементов территории многослойного археологического памятника. Второе обстоятельство связано с распространением за пределы оборонительных сооружений поселения/селища, которое по материалу (культурная принадлежность, хронология) аналогично тому, 


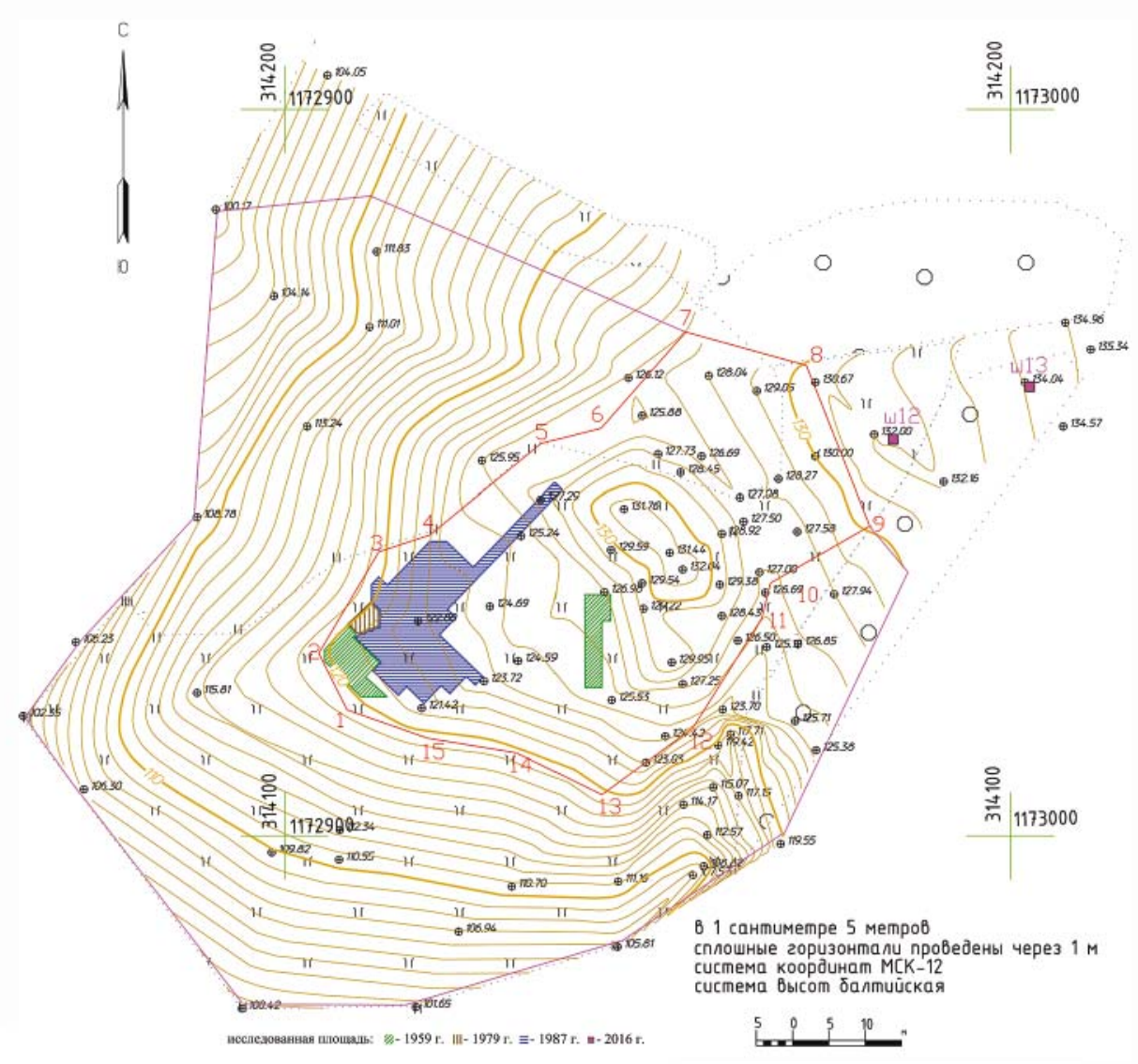

Рис. 4. Пайгусовское городище. Топографический план.

Fig. 4. Paygusovo hillfort. Topographic plan.

что найдено в слоях «жилой зоны» городища. Что, например, прослежено при постановке границ городища «Иванова Гора». Отделять границы городища от границ распространения культурного слоя в таком случае также будет неправильным. Соответственно границы объекта определяются вообще по результатам распространения культурных слоев на всей прилегающей территории. «Иванова Гора» интересна также тем, что открытое поселение раннего средневековья имеется и у подножия городища, но оно не попадает в зону 25 м, которая обозначена в «Методике...» и соответственно должно иметь свои границы. Трудно судить, насколько это правомерно, хотя было бы логично объединить всю территорию в единый комплекс.

Пожалуй, наиболее конкретно в «Методике...» (пункте 7.6.9.) сказано об определении границ курганных могильников: «Граница территории одиночного объекта археологического наследия также может быть определена с учетом возможных визуально не фиксируемых сооружений. В этом случае граница территории одиночного объекта археологического наследия может быть определена на расстоянии 


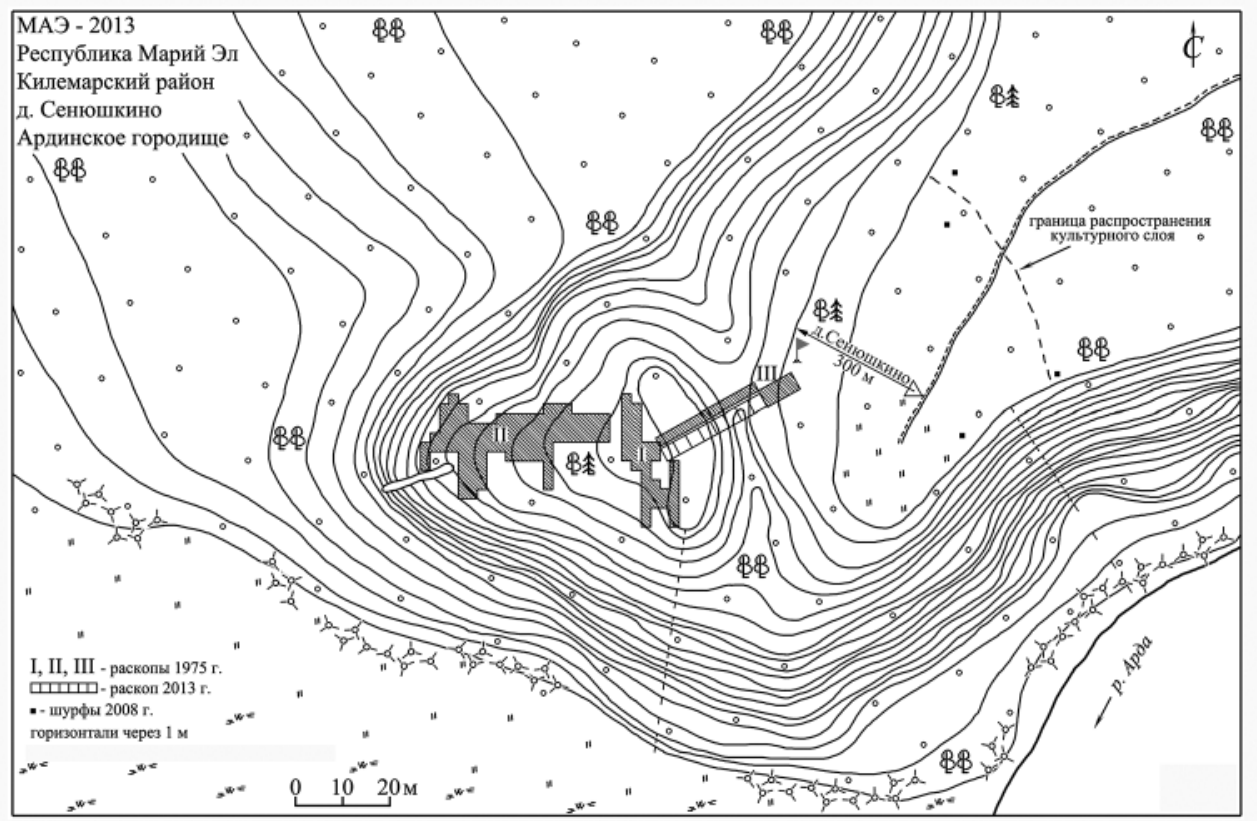

Рис. 5. Ардинское городище. Топографический план.

Fig. 5. Ardy hillfort. Topographic plan.

от 2-х м от подошвы насыпи, внешнего периметра сооружений, ориентировочных границ элементов объекта археологического наследия; указанное расстояние не должно превышать 25 м». К сожалению, опыта определения границ курганов/курганных могильников пока нет, наличие курганно-грунтовых могильников (типа Климкинского) остается большим вопросом. Опыт раскопок курганных групп (на территории Марий Эл представлены памятниками абашевской культуры) показывает, что сооружений, культурного слоя и находок за пределами насыпей нет.

В 2016 году впервые была проведена работа по определению границ территорий грунтовых могильников. Данный вид памятников является наиболее сложным в части определения границ, поскольку главной задачей является локализация места рас- пространения погребений. По сути, грунтовые могильники не имеют культурного слоя и состоят из множества отдельных объектов - погребений. Погребения могут располагаться рядами и группами. Между рядами и группами может быть (часто именно так и есть) расстояние более $5 \mathrm{M}$. В результате установлено, что наиболее точным методом определения границ территории памятника применительно к данному типу объектов археологического наследия, является постановка траншей. Большую роль при этом играет ориентация погребений. Например, поскольку ориентация погребений на Пайгусовском могильнике - север-юг, - для большей вероятности попадания на могильное заполнение траншеи забивались по линии северо-восток - юго-запад (рис. 6). Поскольку ранее на этом памятнике было вскрыто 11 погребений 


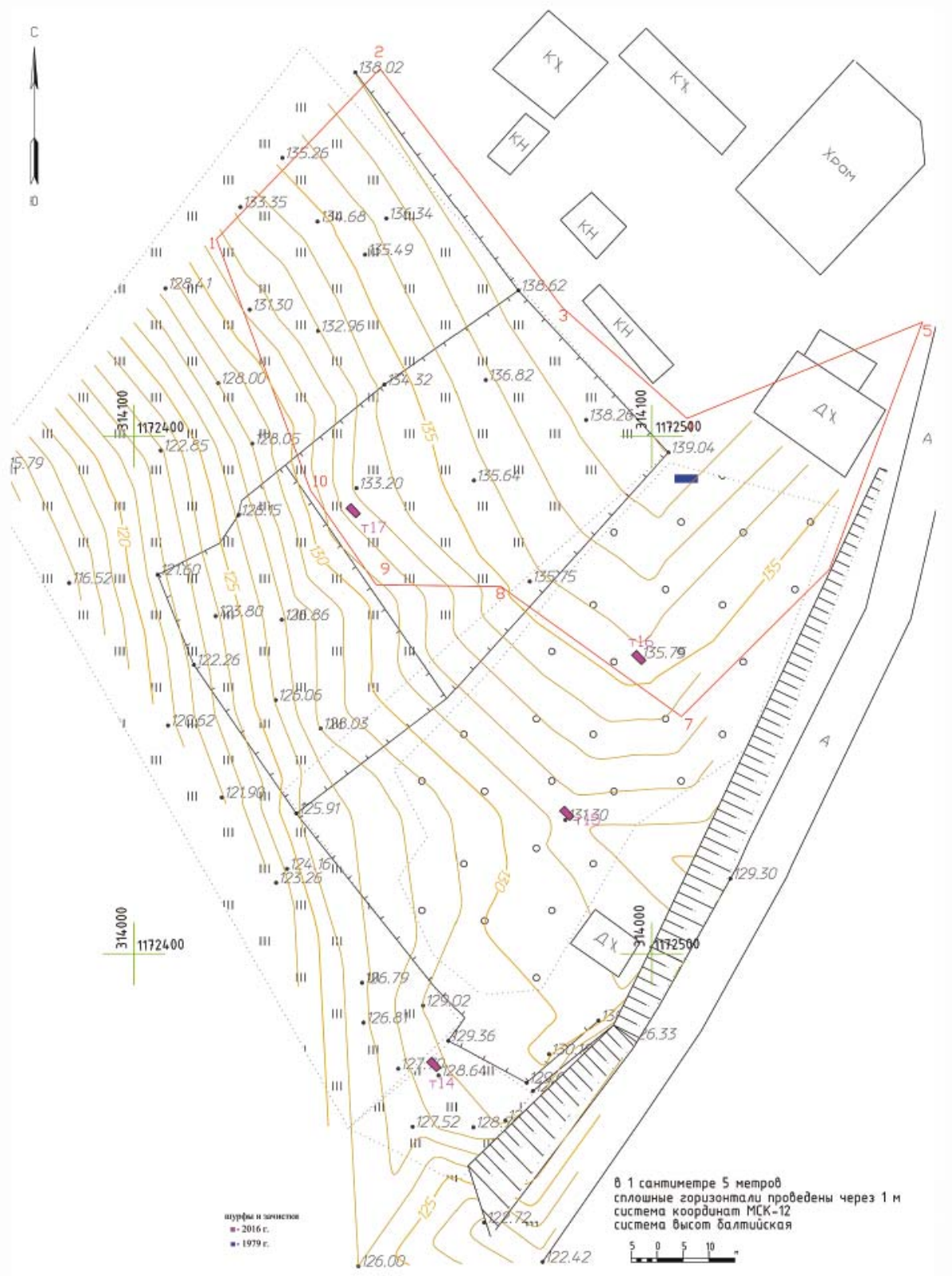

Рис. 6. Пайгусовский могильник. Топографический план.

Fig. 6. Paygusovo burial ground. Topographic plan.

и установлены культурная и хронологическая принадлежность памятника (Горюнова, 1937, с. 279-284; Архипов, Шикаева, 1979, с. 180), необходимость вскрывать погребения, обнаруженные в ходе определения границ территории, отсутствовала. Таким образом, погребения фиксировались на уровне обнаружения, наносились на план и консервировались. Данная методика 
является наиболее приемлемой именно для установления границ грунтовых могильников.

В ходе работ текущего года возникла необходимость в доработке и корректировке методики определения границ памятников археологии. При этом важно отметить, что п. 1.4. «Методики...» дает весьма широкие возможности: «Территориальные органы охраны объектов культурного наследия Министерства культуры Российской Федерации, органы охраны объектов культурного наследия субъектов Российской Федерации вправе дополнять положения настоящей Методики с учетом археологической, ландшафтно-топографической и хозяйственной специфики отдельного региона. Региональные дополнения настоящей Методики должны основываться на принятых методиках археологических исследований в конкретном регионе и согласовываться в Учреждении Российской академии наук Институте археологии РАН (ИА РАН)».

В заключение хотелось бы указать на то, что обращает на себя внимание при проведении исследований по определению границ, а особенно при написании отчета о проделанной работе. Будем руководствоваться тем, что археологические работы предполагают: a) археологические разведки; б) археологические раскопки; в) археологические наблюдения (п. 2. Правил). Во-первых, согласно существующей законодательной базе и сопутствующей документации («Методика определения границ», «Положение о порядке производства археологических работ») на памятниках с определенной культурной и хронологической позицией шурфовка не допускается. Однако при рабо- тах по определению границ это неизбежно. Во-вторых, «Открытый лист для работ по определению границ» выдается с формулировкой «археологические разведки с осуществлением локальных земляных работ...». Это предполагает закладку на одном объекте шурфов объемом не более 20 кв.м. Практика показала, что при определении границ средневековых селищ, топографические границы которых не выражены, количество шурфов превышает допустимые при разведочных работах объемы (рис. 7). Границы грунтовых могильников шурфами $1 \times 1$ или $2 \times 2$ м также не определить - необходима закладка траншей, что опять же неизбежно ведет к превышению допустимых к вскрытию площадей. Будет ли оправдана ссылка на пункт 7.6.12 «Методики...», которая гласит: «Во всех случаях определение границы территории объекта археологического наследия происходит с учетом индивидуальных особенностей исследуемого объекта», - сказать трудно. Однако существующее противоречие между двумя основополагающими документами - «Методикой...» и «Положением...»- следует каким-то образом устранять.

В целом наиболее важными положениями «Методики...», которыми, собственно, и следует руководствоваться при работах по определению границ объектов археологического наследия, являются пп. 6 и 7, в которых, по сути, определено понятие того, что входит в территорию ОАН и соответственно подлежит охране в пределах границ, установленных в ходе архивных и полевых исследований.

Работа по определению границ объектов археологического наследия, 


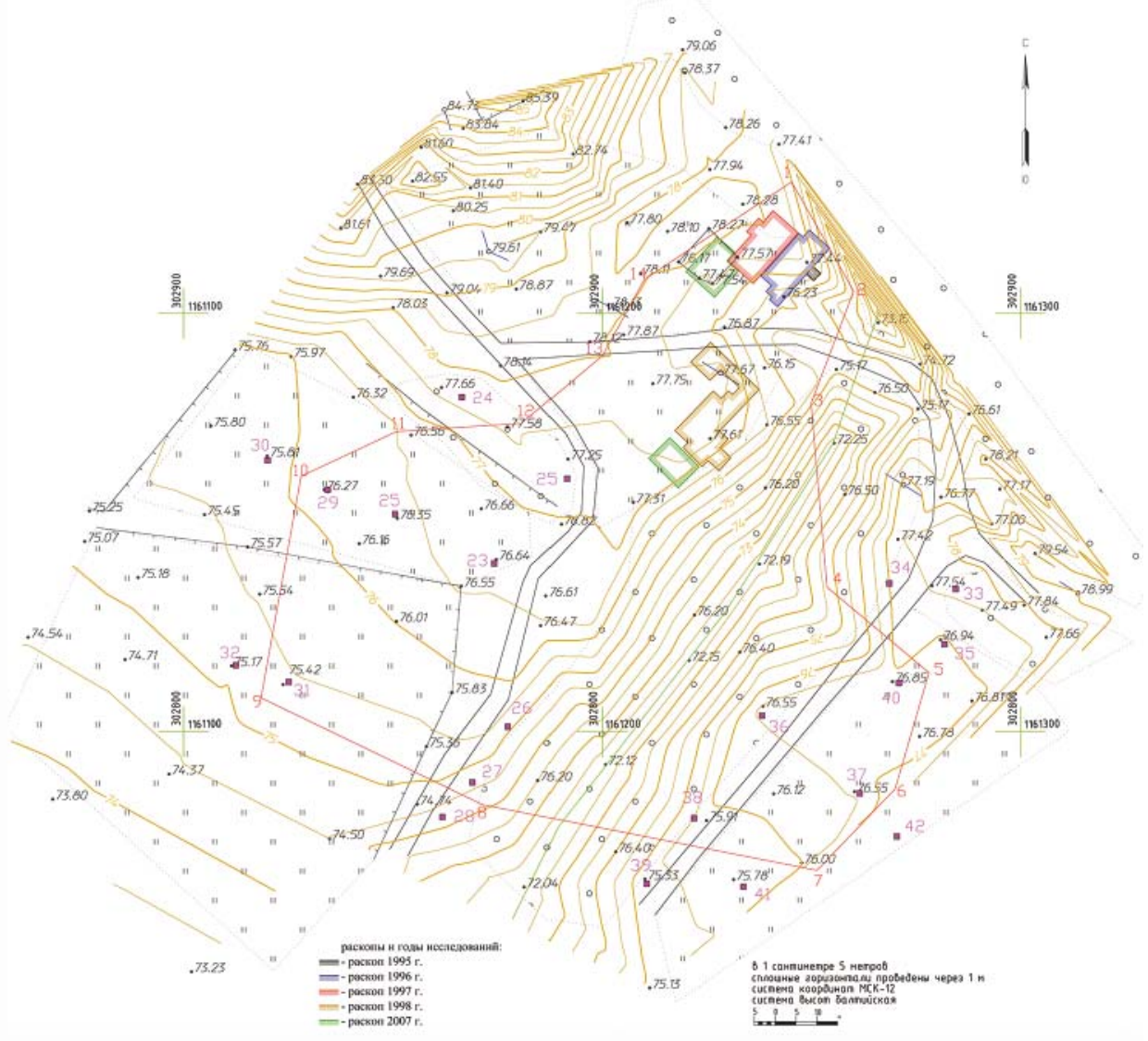

Рис. 7. Красное Селище, селище II. Топографический план.

Fig. 7. Krasnoye Selische, unfortified settlement II. Topographic plan.

является, пожалуй, самым действенным механизмом по предотвращению разрушения памятников в результате хозяйственной деятельности. Данное направление важно и в плане обеспечения государственного учета памятников, поскольку в ходе работ значительно корректируются учетные данные объектов археологии, определяется техническое состояние памятников, уточняется датировка. Матери- алы дают обоснование для внесения изменений в землеустроительную, лесоустроительную и градостроительную документацию. В целом это позволяет Госоргану оперативно вносить сведения для регистрации объектов в Едином государственном реестре объектов культурного наследия (памятников истории и культуры) народов Российской Федерации.

\section{ЛИТЕРАТУРА}

1. Акилбаев A.B. Отчет о работах по определению границ территорий объектов историко-культурного наследия в Килемарском и Юринском районах Республики Марий Эл в 2012 году / НРФ МарНИИЯЛИ. Оп. 1. Д. 1211. 
2. Архипов Г.А., Шикаева Т.Б. Отчет о раскопках МарАЭ за 1979 г. / Архив ИА РАН. P-1. № 7688.

3. Горюнова Е.И. Археологические разведки на территории горного правобережья Волги в пределах Марийской ССР // СА. Т. 4 / Отв. ред. В.В. Струве. М.-Л.: Изд-во АН CCCP, 1937 С. 279-284.

4. Ефремова Д.Ю. Отчет о результатах разведочных работ на территории Горномарийского района РМЭ летом 2011 года (Том II) / НРФ МарНИИЯЛИ. Оп. 1. Д. 1146.

5. Ефремова Д.Ю. Отчет о результатах разведочных работ на территории Республики Марий Эл в 2012 году (Горномарийский и Звениговский районы) (Том II) / НРФ МарНИИЯЛИ. Оп. 1. Д. 1181.

6. Методика определения границ территорий объектов археологического наследия, рекомендованной к применению с 1 января 2012 года (письмо Министерства культуры РФ № 12-01-39/05-АБ от 27 января 2012 г.) // http://7law.info/russia/government1f/s383.htm (дата обращения: 02.12. 20016)

7. Михеев А.В. Научно-исследовательские археологические работы (разведки) на территории Килемарского района РМЭ / НРФ МарНИИЯЛИ. Оп. 1. Д. 1193.

8. Михеев А.В. Научно-исследовательские археологические работы (разведки) на территории Звениговского района РМЭ / НРФ МарНИИЯЛИ. Оп. 1. Д. 1185.

9. Михеев A.B. Определение границ территории объектов археологического наследия в Звениговском районе РМЭ в 2015 году (в 2-х томах) / НРФ МарНИИЯЛИ. Оп. 1. Д. 1209.

10. Никитин B.B. Отчет о разведках в зоне газопровода Уренгой-Помары-Ужгород в Звениговском районе (1991). Йошкар-Ола, 1991 / Архив ИА РАН. Ф. Р-1. Д. 16246.

11. Никитин В.В., Соловьев Б.С. Поселения и постройки Марийского Поволжья (эпоха камня и бронзы) / Труды МарАЭ. Т. VII. Йошкар-Ола: МарНИИЯЛИ, 2002. 162 с., илл.

12. Об утверждении Правил выдачи, приостановления и прекращения действия разрешений (открытых листов) на проведение работ по выявлению и изучению объектов археологического наследия. Утверждены постановлением Правительства Российской Федерации от 20 февраля 2014 года N 127 // http://docs.cntd.ru/document/499077970 (дата обращения: 02.12.2016).

13. Положение о порядке проведения археологических полевых работ и составления научной отчетной документации (Утверждено постановлением Отделения историкофилологических наук Российской академии наук от 27 ноября 2013 г. № 85 // http://www. archaeolog.ru/media/2014/Polozhenie_opi_12-02-14.pdf (дата обращения: 02.12.2016).

\section{Информация об авторе:}

Михеев Алексей Викторович, кандидат исторических наук, заведующий отделом, МарНИИЯЛИ им. В.М. Васильева (г. Йошкар-Ола, Россия); miheev.alexey@mail.ru

\section{DELINEATING SITES OF ARCHAEOLOGICAL HERITAGE: METHODOLOGY BASED ON ENDEAVOURS OF THE MARI ARCHAEOLOGICAL EXPEDITION}

\section{A.V. Mikheev}

The article analyzes the experience of the Mari Archaeological Expedition from 2011 to 2016 to delineate the boundaries of cultural (archaeological) heritage sites by applying the methodology recommended by the Ministry of Culture of the Russian Federation. Practical experience helped generating a number of recommendations on how to improve some techniques applied to different types of sites on the territory of Mari El. The author made a few proposals on how to bring methodological provisions in compliance with the Field Regulations of the Institute of Archaeology of the Russian Academy of Sciences and the relevant legislation on protection of cultural heritage. 
Keywords: archaeology, Volga-Kama region, Mari El Republic, Mari Archaeological Expedition, archaeological site, borders of archeological site, cultural heritage, methodology.

\section{REFERENCES}

1. Akilbaev, A. V. 2012. Otchet o rabotakh po opredeleniiu granits territorii ob"ektov istoriko-kul'turnogo naslediia v Kilemarskom i Iurinskom raionakh Respubliki Marii El v 2012 godu (Report on Fieldworks for Demarcation of the Borders of Objects of the Historical and Cultural Heritage in Kilemary and Yurino Districts, Mari El Republic, in 2012). Collection of scientific manuscripts, Mari Language, Literature, History and Ethnography Scientific and Research Institute. Inv. 1, dossier 1211 (in Russian).

2. Arkhipov, G. A., Shikaeva, T. B. 1979. Otchet o raskopkakh Mariiskoi arkheologicheskii ekspeditsii za 1979 g. (Report on Excavations of the Mari Archaeological Expedition in 1979). Archive of the Institute of Archaeology of the Russian Academy of Sciences. R-1, no. 7688 (in Russian).

3. Goriunova, E. I. 1937. In Struve, V. V. (ed.). Sovetskaia Arkheologiia (Soviet Archaeology) IV. Moscow; Leningrad: Academy of Sciences of the USSR, 279-284 (in Russian).

4. Efremova, D. Yu. 2011. Otchet o rezul'tatakh razvedochnykh rabot na territorii Gornomariiskogo raiona Respubliki Marii El letom 2011 goda (Report on Results of Archaeological Surveys in the Gornomariysky District, Marii El Republic, in the Summer of 2011) II. Scientific Hand-Written Fund of the Mari Scientific and Research Language, Literature, History and Ethnography Institute. Inv. 1, dossier 1146 (in Russian).

5. Efremova, D. Yu. 2012. Otchet o rezul 'tatakh razvedochnykh rabot na territorii Respubliki Marii El v 2012 godu (Gornomariiskii i Zvenigovskii raiony) (Report on Results of Archaeological Surveys in the Marii El Republic in 2012: Gornomariysky and Zvenigovsky Districts) II. Scientific Hand-Written Fund of the Mari Scientific and Research Language, Literature, History and Ethnography Institute. Inv. 1, dossier 1181 (in Russian).

6. Metodika opredeleniia granits territorii ob"ektov arkheologicheskogo naslediia, rekomendovannoi k primeneniiu s 1 ianvaria 2012 goda (pis'mo Ministerstva kul 'tury RF № 12-01-39/05-AB ot 27 ianvaria 2012 g.) (Approach to Delineation of Archaeological Heritage Sites' Territories, recommended for application from 1 January 2012 (letter from the RF Minsitry of Culture, no. 12-01-39/05-AB of 27 January 2012)). Available at: http://7law.info/ russia/government1f/s383.htm (accessed 02.12. 2016) (in Russian).

7. Mikheev, A. V. Nauchno-issledovatel'skie arkheologicheskie raboty (razvedki) na territorii Kilemarskogo raiona RME (Research Archaeological Fieldworks (Field Surveys) on the Territory of the Kilemary District, Mari El Republic). Scientific Hand-Written Fund of the Mari Scientific and Research Language, Literature, History and Ethnography Institute. Inv. 1, dossier 1193 (in Russian).

8. Mikheev, A. V. Nauchno-issledovatel'skie arkheologicheskie raboty (razvedki) na territorii Zvenigovskogo raiona RME (Research Archaeological Fieldworks (Field Surveys) on the Territory of the Zvenigovsky District, Mari El Republic). Scientific Hand-Written Fund of the Mari Scientific and Research Language, Literature, History and Ethnography Institute. Inv. 1, dossier 1185 (in Russian).

9. Mikheev, A. V. 2015. Opredelenie granits territorii ob"ektov arkheologicheskogo naslediia $v$ Zvenigovskom raione RME v 2015 godu (Delineation of Territories under Archaeological Heritage Sites in the Zvenigovsky District, Mari El Republic, in 2015) (in 2 vols.). Scientific Hand-Written Fund of the Mari Scientific and Research Language, Literature, History and Ethnography Institute. Inv. 1, dossier 1209 (in Russian).

10. Nikitin, V. V. 1991. Otchet o razvedkakh $v$ zone gazoprovoda Urengoi-PomaryUzhgorod v Zvenigovskom raione (1991) (Report on Archaeological Surveys in the Area of 
the Urengoy-Pomary-Uzhgorod Gas Pipeline in 1991). Yoshkar-Ola. Archive of the Institute of Archaeology of the Russian Academy of Sciences. Fund R-1, dossier 16246 (in Russian).

11. Nikitin, V. V., Solov'ev, B. S. 2002. Poseleniia i postroiki Mariiskogo Povolzh'ia (epokha kamnia i bronzy) (Settlements and Dwellings of the Mari Volga Region: Stone and Bronze Ages). Series: Trudy Mariiskoi arkheologicheskoi ekspeditsii (Proceedings of Mari Archaeological Expedition) VII. Yoshkar-Ola: Mari Scientific and Research Language, Literature, and History Institute (in Russian).

12. Ob utverzhdenii Pravil vydachi, priostanovleniia $i$ prekrashcheniia deistviia razreshenii (otkrytykh listov) na provedenie rabot po vyiavleniiu $i$ izucheniiu ob"ektov arkheologicheskogo naslediYa. Utverzhdeny postanovleniem Pravitel'stva Rossiiskoi Federatsii ot 20 fevralia 2014 goda N 127 (On approval of the Regulations for issuance, withdrawal and termination of authorizations (permissions for archaeological works) to carry out exploration and investigations activities on archaological heritage sites. Endorsed by the Directive of the RF Governmnet no. 127 of 20 February 2014). Available at: http:// docs.cntd.ru/document/499077970 (accessed 02.12.2016) (in Russian).

13. Polozhenie o poriadke provedeniia arkheologicheskikh polevykh rabot i sostavleniia nauchnoi otchetnoi dokumentatsii (Utverzhdeno postanovleniem Otdeleniia istorikofilologicheskikh nauk Rossiiskoi akademii nauk ot 27 noiabria 2013 g. № 85) (Regulations of archaeological fieldworks and scientific reporting (approved through Decision no. 85 of the History and Philology Department of the Russian Academy of Sciences on 27 November 2013)). Available at: http://www.archaeolog.ru/media/2014/Polozhenie_opi_12-02-14.pdf. (accessed 02.12.2016) (in Russian).

\section{About the Authors:}

Mikheev Alexey V., Candidate of Historical Sciences. Mari Research Institute of Language, Literature and History named after V.M. Vasilyev. Krasnoarmeyskaya St., 44, Yoshkar-Ola, 424036, Mari El Republic, Russian Federation; miheev.alexey@mail.ru 